\title{
In A Word: The Importance of Shakespeare's Subtexts
}

Lorelei Cederstrom

Brandon University

\begin{abstract}
The subtexts of Shakespeare's plays often provide surprisingly accurate insights not only into the central themes of the plays, but also a greater understanding of the unifying elements. The subtexts from a representative sampling of plays from each of the major periods reveals that such subtextual elements as repeated words, near synonyms and recurrent images are fairly accurate assessors of the playwright's central intent. The best way to approach the plays is through a method that considers not only the text and plot, but the poetic devices that arise by considering the subtext. This study explores the nature-nothing subtext in King Lear, the seeing-seeming disparity in Othello, the repeated references to chains and gold in $A$ Comedy of Errors, the explorations of fortune in As You Like It, the persistent emphasis on words and voices in Coriolanus, and the subtextual significance of wonder and rebellion in The Tempest. In each case, attention to the sound devices, repetitions and patterns of imagery yields a more thorough understanding of the play under consideration than the standard imagery studies or plot analyses.
\end{abstract}

Those of us who teach Shakespeare primarily to undergraduates find that most of our class time is taken up with explication, as students are confounded not only by the peculiarities of Elizabethan English but also by the complexities of Shakespeare's themes. As a result, we find ourselves discussing plot rather than poetics. An approach to the plays that begins with the subtext, however, will enable the teacher and student alike to become more directly involved with the artistry of the plays. Each of the plays is a poem, after all, and yields to an approach that recognizes its poetic structures and harmonies. The poetic structures of the plays have often been compared to tapestries, and, like tapestries, demonstrate a complexity of colour and texture. The subtext, like a thread in the elaborate design, can be utilized as a means of approach to the whole. Tug at a single strand of Shakespeare's tapestry and the thread will lead you toward the central pattern. Because Shakespeare was a conscious artist with total control of his material, close attention to repetitions and seemingly innocuous "threads" will provide a means of approaching the whole that is accessible to most students. 
The subtext is a simple means by which students can bring the larger ideas of the works into focus. The subtext is a part of the poetry of the text which lies beneath the plot, including the patterns of imagery, the sound devices-particularly words which are repeated so often that they take on a life of their own as sound, rather like a leit motif in music-and all the connotations that arise from the juxtaposition of the repeated words and images in new contexts. A sensitivity to the subtext reveals that the repeated tollings of a single word and its variants often have reverberations through the play as a whole. The great directors have been sensitive to the nuances of the subtext in preparing for their productions. Charles Marowitz, for example, Peter Brook's Assistant Director for the 1969 film of King Lear, wrote about the subtext for the Tulane Drama Review (8 [1953]). Marowitz's essay is a rhapsodic poem in itself on the subtextual words that he and Brook had emphasized in the 1962 stage production. Although critics like G. Wilson Knight and Caroline Spurgeon had written about the patterns of imagery in the play, Brook carried the idea one step further, paying particular attention to repeated words, or words that appear in new contexts (and which take on new meanings as a result) in different parts of the play. Examination of sounds of the subtext reveals that Shakespeare's plays were written to be heard, and that many of his meanings are emphasized through sounds that are picked up almost subliminally by dint of repetition, or by the use of several words in succession that are similar in sound with related meanings. A comparison of the standard imagery studies of King Lear with the Brooks/Marowitz essay is instructive.

In Leading Motives in the Imagery of Shakespeare's Tragedies, Caroline Spurgeon notes the recurrence of images of torture in King Lear which she finds to be often linked with animal images. She notes that these images flow naturally from the drama and mental suffering of Lear. The sensation of Lear's pain is increased by means of verbs and metaphors of a human body in anguished movement: "a body tugged, wrenched, beaten, pierced, stung, dislocated, flayed, gashed, scalded, tortured and finally broken on the rack" (29-30). G. Wilson Knight, in The Wheel of Fire emphasizes, as the title suggests, the same ideas. These patterns of imagery are, obviously, central to the drama of Lear's painful discovery of himself and of the meaning of love. Peter Brook, however, has explored some of the other word patterns in the play and has developed his production of the work around four repeated words: nature, nothing, foolish and blindness. These words are those which a concordance tells us appear most often in the play, and each one is linked to the others in different contexts as the play proceeds.

Students can readily utilize an approach like Brook's to this play by the simple exercise of keeping their ears open for the single word in the play which is on everyone's lips. "Nature" is readily located since it is repeated (if you include its negative form) fifty-five times. Once the word "nature" has been located, the next step is to ask why Shakespeare has called our attention to this word. What does nature mean? Does nature mean the same thing to everyone who uses the word? And, finally, how does nature relate to the work as a whole? Proceeding with a single word, like nature, as a tool, eventually one can uncover the central meanings of the play. Virtually every work of criticism on King Lear includes a statement about nature. Derek Traversi in Stratford Papers on Shakespeare calls Lear an allegory of "man's relation to nature." L. C. Knights in Some Shakespearean Themes says the play attempts to answer the question: "What is essential 
buman nature?" Robert Heilman in This Great Stage believes the play is "an essay upon nature," and H. B. Charlton offers an important discussion of the theme of nature in Shakespearean Tragedy. As well, John Danby in Shakespeare's Doctrine of Nature, explores the various uses of the word nature throughout the play. Clearly the word is central to the meaning as well as the poetry of the work. The students' interest in the play is greatly stimulated by letting them make the discovery of this central word, unravelling for themselves the reasons for its prominence rather than telling them that many critics feel nature to be central to the meaning of the play. Using the inductive method will also lead to an exploration of the poetry of the play. Students will become aware of connotation when they consider what the word nature means when the "natural" i.e. illegitimate, son, the bastard, Edmund, calls upon Nature as his "Goddess." They will become aware of the irony of Lear calling his loving daughter, Cordelia, a "wretch whom nature is asham'd almost t'acknowledge hers," and of the doubled irony when the "natural" son, Edmund, convinces his father that his brother, Edgar, is an "unnatural detested brutish villain." The student will also become aware of analogy and allusion through the idea of the "natural order" in the Renaissance, when Edmund draws our attention to the dire consequences for the cosmos when there is "unnaturalness between the child and the parent."

The student will also discover, as Peter Brook did, that the word nature is frequently linked to the word nothing, which occurs in different contexts throughout the subtext. Cordelia's response to her father's demand for a word of love is "nothing," which he repeats in bewilderment and she repeats in affirmation until it rings in our ears in all its emptiness. Lear's response that "Nothing will come of nothing" picks up new connotations in each subsequent act of the play as Lear is stripped of everything he is and everything he thought he was. When his daughters, who will "allow not nature more than nature needs," strip Lear of his attendants, Lear finds a nothing in nature; Edgar, disguised as natural man, shows Lear "Man's life as cheap as beasts." The "unnatural hags," Goneril and Reagan, force Lear to confront the state of bare nature. Eventually Lear, like Edgar, "nothing is."

In a similar vein, the words foolish and blindness are linked with the word nature and reverberate through the subtext, for Lear must become a "fool of nature" before he can become wise. Lear, like Gloucester, was blind when he had eyes, and learns true sight when he "sees feelingly" the natural beauty of his loving daughter.

Looking at the subtext in several other plays, we can find a similar amplification of the playwright's ideas and insight into his poetic method. To consider, first, another tragedy, the subtext in Othello similarly amplifies and focuses the central themes. As has been noted by William Empson and every critic since, the word repeated most often in Othello is honest. "Honest, honest Iago" deceives everyone into seeing him as he is not. Everyone in the play calls him "Honest Iago" including those whom he most deceives: Desdemona, Cassio, Othello, and his own wife, Emilia. The word takes on a bitter irony when dishonest "honest Iago" casts doubt upon the honesty of Cassio by refusing to firmly attach the word to Cassio at Othello's bidding. The best Iago can manage is the assertion that "I dare be sworn I think that he is honest" (III.III.125). Iago forces Othello similarly to question Desdemona's honesty (in the Renaissance honesty also implied chastity) until Othello is left with the confused idea that "I do not think but Desdemona's honest." The irony is 
more bitter following as it does upon straightforward and unequivocal assertions of Iago's honesty by everyone in the play. This aspect of the play is straightforward and understood by most readers.

The subtext, however, adds another layer to the ironies through the use of words which sound so much alike that one almost hears both words when one is sounded. These repeated words are see, and seem. The words see/seen/saw appear forty-eight times in the play; the words seem or seeming twelve times. The association which is made by the ear through the sound brings us to the heart of the conflict in the play which involves the difference between seeing and seeming. Iago tells us in the first scene that he is not "for love and duty" but "seeming so, for my peculiar end." As noted, everyone sees him as honest and loyal but this is due only to his seeming so.

The idea of seeing and seeming is linked to Desdemona in the first act of the play as well. Brabantio is a deceived father; he has seen no signs that his daughter was in love with Othello and is genuinely convinced that Othello must have used charms or magic upon her to bring about their marriage. He warns all Fathers to "trust not your daughter's mind/By what you see them act"-thereby calling the audience's attention to the difference between what seems to be true and what is finally seen to be true.

The third scene in Act I amplifies the problems of seeming and seeing. The Duke and the Senators are in a state of confusion as to whether the Turks plan to attack Rhodes as they seem to be doing or whether they will attack Cyprus which would make more political sense. The Senators realize, finally, that the Turks must be moving toward Cyprus, and the movement toward Rhodes is "a pageant to keep [them] in false gaze." Here, the emphasis on seeing as deception in the subtext of a subsidiary scene points toward the central issues once again. In this same scene, the charges of witchcraft which Brabantio brings to the Duke about Othello are seen through immediately by the Duke as "poor likelihoods of modern seeming." Although Othello himself is free of any "false gaze" and is able to present himself in such a way that everyone can see his worth clearly, Shakespeare reiterates the idea of a false show in Brabantio's parting words to his daughter's husband: "Look to her, Moor, if thou hast eyes to see/She has deceiv'd her father and may thee."

Indeed, in Iago's soliloquy which concludes Act I, we learn that Othello's tragic flaw and the agent which will bring about his downfall is connected to the business of seeing and seeming. Iago notes "The Moor is of a free and open nature/That thinks men honest that but seem to be so." The action of the play focuses upon Iago's use of this idea. If Othello thinks men honest that but seem to be so, all Iago has to do is to let Othello think Desdemona dishonest by making her seem to be so.

Iago's great gift in cunning lies in his ability to create "false pageants" in people's minds, so that they see only the images that Iago has created for them. Cassio for example, admits to a "poor head" for drinking and lago convinces everyone that this is a serious problem. He encourages Montano to "see this fellow" and "see his vice." When Iago has fanned Cassio's poor head for drinking into a general mutiny in Cyprus, Othello is forced to question Iago at Montano's urging in the face of a "seeming" reluctance to speak about what he has seen in Cassio. The end result is that the seeming flaw which Iago has 
produced carries more weight than the actuality of Cassio's observed performance under Othello, and he is dismissed.

The climax of the play, the "Temptation Scene," Act III, scene iii, wherein Iago convinces Othello of Desdemona's unfaithfulness, likewise is filled with words that refer to seeing and seeming. When Iago first casts aspersions upon Desdemona's chastity, Othello's response is: "she had eyes and chose me. No, Iago;/l'll see before I doubt." lago warns Othello simply to use his eyes:

Look to your wife, observe her well with Cassio;

Wear your eye thus, not jealous nor secure

... Look to it

I know our country disposition well;

In Venice they do let heaven see the pranks

They dare not show their husbands. (III.III.198-203)

On an unconscious level, this has a powerful impact upon Othello. Brabantio felt his daughter could seem to be one thing but be another, and since Othello does not know the world of Venice, he has to assume that what lago tells him about the custom of Venetian dissembling is correct. Othello's fate is sealed when Iago reminds him of Brabantio's wounds: "She that, so young, could give out such a seeming,/to seal her father's eyes up close as oak" (III.III.209-10). When Othello holds back, retaining some fondness for his wife, Iago provides Othello with images of Cassio's love and Desdemona's response so vivid that Othello believes he sees them. Just as Iago created the image of the "beast with two backs" to enrage Brabantio, so he creates verbal images of copulating animals and suggests that even were Desdemona and Cassio as "prime as goats, as hot as monkeys" (III.III.403) it would be impossible that Othello should "see her topp'd." Iago skillfully adds incriminating image to image as he describes Cassio's alleged sleeptalking and the gestures in which Cassio's thigh fell upon his own, and Cassio's lips touched Iago's, whispering "Sweet Desdemona." Having created this "false pageant" which affects the Moor with all the credence of actual seeing, Iago then holds back, asking Othello to wait for more proof noting: "We see nothing done: she may be honest yet."

Othello, however, has been a man not easily shaken by words, nor influenced by opinions of others. He demands an "ocular proof." If he had stopped with this directive, Desdemona might have been saved, but it is too late, for Iago's portraits of her adultery have captured him with all the vividness of seeing. This is emphasized when Othello is distracted from state business muttering "goats and monkeys" (IV.I.254). The final ocular proof, the handkerchief which convinces Othello of his wife's adultery, would be an absurd basis for taking the life of one's spouse were it not prepared for by all these other "seeming" proofs and by the constant reiteration of the importance of seeing in all these other situations. Even the image of the handkerchief as proof of adultery is created more vividly for Othello's mind's eye than it exists in reality when Iago tells Othello that he saw Cassio wipe his beard with it.

The fact that Iago controls what is seen is emphasized through the subtext of the first scene of the last act, the scene in which Cassio is wounded by Roderigo. Everyone is 
fumbling around in the dark here; so that Roderigo wounds Cassio, and Iago kills Roderigc in the midst of confused voices on all sides asking questions. Who is calling for help? Whe is the assassin? Who the defender? Is someone really in trouble or is this the work of thieves? lago enters in the midst of the confusion he has caused, bringing a light which symbolizes his ability to make people see what he wants them to see. His light is the light of Lucifer whose rationalizing creates a view of reality that seems to make sense.

In the denouement, all the characters who believe what they have seen, are informed that it has only seemed so. In the end, Othello has seen only a handkerchief and all else has been the artful illusion created by a man whose seeming honesty has led credence to a false gaze, the vivid seeming of false pageants. In a word, the idea of seeing or seeming in the subtext directs the audience toward the central conflict and provides a unifying link between various minor scenes in the play. In each case the central issue is identical to Othello's main question-Do I see or do I seem to see? In the end, Othello's ocular proof has deceived him because he had been unable to do what Lear and blind Gloucester were able to do, to "see feelingly," to see the blackness in Iago and the spiritual innocence of Desdemona with his heart rather than his eyes.

Although this method works best with the unified later plays, Shakespeare's earliest works, the comedies, can also be amplified by attention to the subtext. However, since the themes and structures of Shakespeare's comedies are less demanding to explicate, the subtexts, also, yield more direct insights than they do in the later work. They do, however, help to explain minor problems in the structure and assist in clarifying the central issues of the plays. Even in Shakespeare's first comedy, the repeated words in the subtext amplify the moral vision of the work. Virtually everyone who has written about $A$ Comedy of Errors has noted the recurring references to chains and gold. Since the chains of emphasis are made of gold, and since the play involves family bonds and several sets of marriage partners, the images connote wedding rings and the golden bonds of social ceremonies. Richard Henze in his essay, "The Comedy of Errors: A Freely Binding Chain," directs our attention to the relationship between the image of the chain and the idea of social bonds. He notes, and most critics would agree with his assessment, that the theme of the play involves the paradox of "finding oneself by losing oneself and the freeing of one's self by binding oneself" (36). The forty-five references to chains and the thirty references to gold and goldsmiths point the audience as well toward the philosophical stance of the play. Harold Brooks in "Themes and Structures in The Comedy of Errors" writes: "At the centre is relationship: relationship between human beings, depending on their right relation to truth and universal law: to the cosmic reality beneath appearance, and the cosmic order" (68).

While this is true enough, the subtextual images of chains and gold take on a different light when looked at in the context of the enveloping action of the story. Shakespeare's primary contribution to the source is his addition of the framing story of Aegeon and Emilia, the aging parents of the twins whose errors form the comedy. The image of chains takes on a more sinister aspect in terms of the parents, for the play opens with Aegeon in chains and a punishment by death threatening the old man. The first line of the play is Aegeon's plea for a quick death to end his anguish. Here, the chains which bind Aegeon are those of the debtor's prison, and gold is the price of his redemption. The Duke tells 
him "Beg thou, or borrow, to make up the sum/And live; if no; then thou are doomed to die" (I.I.154-56). This image of an old man in chains waiting for the gold which will set him free forms a dark counterpoint to the glitter of the gold and golden chains that occupies so much of the conversation and attention of the characters in the body of the play.

The first error in the comedy involves gold coins. One servant is beaten for losing money given to his twin, and the word money enters the subtext alongside the word gold so that we can see that this is base gold that the characters are pursuing. Confusion about money is also interwoven with confusion about one's identity. The beaten servant believes his master has lost his wits: "Sure, he is stark mad./When I desired him to come home to dinner,/He ask'd me for a thousand marks in gold" (II.I.59-61). Each character's identity is defined in terms of money. Those who receive the money belonging to their twins also take on the identity of their brothers. Those who lose the money, lose themselves. Shakespeare is exploring a profound moral problem here, when one's identity is only secondary to the problem of missing money. Toward the end of the play, Antipholus of Ephesus finds himself in chains (a reminder of his father's state) over money. In this case, he has paid his debt to the goldsmith but the money has gone astray in another error of mistaken identity. On a deeper level, Shakespeare reveals that money cannot effect the desired redemption of the characters in the play, nor does the money aid any of the characters in sorting out the errors of identity. Money can be paid, but since Antipholus lacks his own identity, the money does not buy release. This continues until the last scene of the play, when Aegeon is released without paying the ransom. The Duke frees him as a result of the human story of love and loss which he has heard. In the end, the chains that link the members of the family are not made of the kind of gold one can exchange for cash, but are love's golden chains of kinship and community.

Just as the subtext in A Comedy of Errors leads to an understanding of the important issues which have been confused with money, so in As You Like It, the subtext leads more directly to the heart of the play than the imagery studies do. Spurgeon notes that the imagery that dominates this play is drawn from nature, agriculture, and animal life, more so than in any other of Shakespeare's plays. There is nothing startling here, nor unexpected, in finding images of nature, animals and agriculture in a work that utilizes the pastoral conventions of the sixteenth century. The pastoral images lead simply to the main themes of the play which involve an analysis of multifaceted views of love with an end, as Marilyn French has noted, of bringing the reader in touch with "the deep heart of courtship - which is . . . self-knowledge." We are, she notes, presented with "a march and countermarch of self and persona ... geared to the essential purposes of self-discovery and mating" (110).

The subtext directly clarifies the boundaries of this quest for love by penetrating the illusions that prevent us from knowing ourselves or one another. From the beginning, in Orlando's speech which opens the play, we encounter the two structures which form these boundaries of "self-discovery and mating"-nature and fortune. Orlando is poor through fortune but rich in nature, as are the other heros and heroines of the play. Orlando is full of spirit, although his natural gifts have been allowed to fester on a dunghill since his fortune was put in the hands of his older brother. Shakespeare reveals, through frequent 
references to fortune in the subtext, that misfortune alone will not keep the good from surfacing. In a doubling of Orlando's situation, Celia and Rosalind decry the inequities of fortune in which one cousin, Celia, has everything, the other, Rosalind, only forbearance, and decide to "mock the good housewife Fortune from her wheel, that her gifts may henceforth be bestowed equally" (I.II.34-36). Both girls realize that Fortune's gifts may be stolen or borrowed but the gifts of nature are those worth having. Rosalind notes: "Fortune reigns in gifts of the world, not in the lineaments of nature" (I.II.45).

The lovers in the story likewise see through the rank bestowed by fortune and love one another for natural gifts rather than material ones. Each lover affirms the necessity of seeing clearly, of seeing beyond the trappings of fortune to the nature of the beloved. Each recognition before the wedding ceremony which ends the play is prefaced with the words "If there be truth in sight." This suggests that truth lies in seeing beyond ordinary sight, for these weddings would not be taking place if any of them had been content to judge one another on the basis of fortune.

One of the most frequent criticisms levelled against As You Like It is about its lack of structure. Harold Jenkins, for example, comments on the "lack of cause and effect plotting" in the play, and Marc Parrott feels that Shakespeare put "little intellectual labor into the construction of the plot" (518). Yet, this lack of structure can be accounted for by considering the message of the subtext. The world of fortune is the world of plots. The world wherein nature's gifts are seen and felt without regard for fortune is a world where logical processes of cause and effect, the focuses of a world seeking wealth and power, give way to illogical intuition. Fortune's world is the world of the "fat and greasy citizens" of fashion who plot their roles upon fortune's stage, a world which Shakespeare contrasts with the settled low content" enjoyed by fortune's fools in Arden. As Amiens pointed out at the beginning of Act II: "Happy" are those "that can translate the stubbornness of fortune/Into so quiet and so sweet a style" (II.I.19-20).

A more difficult test of the usefulness of the subtext is whether such study can bring one closer to an understanding of a play like Coriolanus whose primary focus is intellectual. Although T.S. Eliot wrote an essay in appreciation of Coriolanus, even the most dedicated Shakespearean finds something elusive and difficult about this play. John Palmer has compared the work to a statue in a public square which one can encircle and appreciate but not take to heart. The imagery studies of this play do not bring one any closer to an imaginative appreciation of the work. Indeed, each of the critics exploring the imagery has come to a different conclusion. Caroline Spurgeon, for example, feels that the central symbol is the image of the body politic presented by Menenius in the first scene of the play, with its emphasis on the belly, the body and sickness. She concludes, however, that this symbol "has not been born out of the creator's feeling of the tragedy; it has just been taken over by him wholesale, with much else from North's Plutarch" (347). Derek Traversi in An Approach to Shakespeare focuses upon the fable of the body politic as well. He concludes that "greed and satiety" are the main images by which we are prepared for the tragedy of Coriolanus" (154). He also observes the preponderance of hard, machinelike images which are attached to Coriolanus and views these as a means of showing his rigid character. "The failure of Coriolanus," he states, "is a failure in sensitivity, a failure in living; it represents a failure on the part of the whole society." G. Wilson Knight in The 
Imperial Theme also emphasizes the hard and metallic nature of the city and war imagery, and links these images to the theme of Coriolanus's iron-hearted pride. He theorizes that just as in Antony and Cleopatra "the two values, love and war oppose each other, so the same contrast is at the core of Coriolanus." Yet, none of these patterns leads us much closer to the central question of what Coriolanus is really about. W. H. Clemens in The Development of Shakespeare's Imagery gets a bit closer. He sees the imagery as emphasizing and repeating the play's main theme, "the contrast between the commanding figure of Coriolanus and the baseness of the rabble" (154).

The studies of the play as a political work carry us a bit farther, for although the play is called The Tragedy of Coriolanus, the tragedy is not one of passion but a political tragedy brought about by the inbred reactions of the soldier protagonist to the political realities of Roman life. Obviously, the playwright could not, as Marc Parrott has noted, sustain interest in a play "whose hero through repellent pride plans the monstrous destruction of his native city" (908). Instead, Shakespeare is concerned with the political process, in particular, with the way that the words of politicians have a life of their own and create a world antithetical to the world created by the men of deeds, the soldiers. Ultimately, the play can be seen as a political play in the truest sense. As A. P. Rossiter notes:

By 'political' I do not mean the class war, nor even narrowly the Tudor system of Godordained order. I mean Coriolanus plays on political feeling: the capacity to be not only intellectually but emotionally and purposively, engaged by the management of public affairs; the businesses of groups of men in (ordered) communities; the contrivance or maintenance of agreement; the establishment of a will-in-common; and all the exercises of suasion, pressure, concession and compromise which achieve that will (a mind to do) in place of a chaos of confused appetencies. (239)

Rossiter's emphasis on the political polarities between a "mind to do" and "confused appetencies" brings us to the primary polarities set out by the subtext. In particular, the play creates a distinction between those who do and those who speak, between men of deeds and men of words, which is amplified in the subtext. While the body imagery that Spurgeon and Traversi note is especially apparent in the first act, it undergoes a radical shift in the later scenes. Menenius's allegory of the body politic with the citizens as the belly appears in Act I, and while vivid, it is a wordy bit of politicking, a means of diverting the citizens from action. The absurd references to the citizens as bellies and big toes are clearly intended as satiric thrusts at Renaissance allegories which compare the order of the state to a healthy body. The subtext emphasizes other parts of the body which are related to the political themes and develop accordingly throughout the work. The two parts of the body that are continually being sounded in the subtext are the tongue and the heart. The tongue is linked to related terms which together form a commentary on empty words. The slow speeches of the politicians on state occasions and the many references to the breath and voices of the people add to the idea of meaningless tongue-wagging, of empty sounds. The heart is linked to Marcius Coriolanus, to his war-like qualities, in particular, to his courage and brave deeds. 
The play opens with words and voices wafting in the wind; the plebians are in a furor over corn prices and looking for redress. The subtext begins to toll the idea of words, of political promises, of the empty voices of the people as a counterpoint to the deeds of the heros like Marcius. "Speak, speak, speak"; the citizens demand words at the beginning of the play. No sooner do the citizen's words of protest turn into a demand for action against Marcius-“-No more talking, let it be done," than the fickle citizens begin to equivocate. They reaffirm their desire to "show 'em deeds," to show not only "strong breath" but "strong arms too" when another voice diverts them, and they listen with strange patience to Menenius's long allegory of the body politic. This opposition set up in the first scene between words and deeds, between decisions for action and equivocation continues throughout the play. Marcius's character is, thus, established in the first scene in opposition to the Plebians; he is one who abhors words and cares not a whit about people who are so readily led by their ears. At the end of this scene the rabble is appeased, not by corn for all their proclaimed hunger, but by the promise of a political voice, a pointed reference to their preference for words.

The next several scenes are taken up with revealing Marcius's brave heart in battle, wherein he proves himself worthy of Rome's highest honors. While men of weaker heart seek safety, he bravely dares to enter the gates of the enemy city and fight unaided. When he is cheered by his men for his valour, he indicates his lack of interest in words of praise: "I have some wounds upon me, and they smart/To hear themselves remember'd" (I.IX.28-29). When the soldiers persist, Marcius, too, is adamant in refusing praise: "You shout me forth/In acclamations hyperbolical,/As if I lov'd my little should be dieted/In praises sauc'd with lies" (I.IX.49-52). The food references suggest that Marcius would prefer that his deeds not help feed the belly of the vocal but cowardly state.

Marcius's character, his inability to accept words of praise or blame is well established before the scene in which he is required to seek the approbation of the people's voices for a consulship (II.III). Before the Senate, Marcius states again and again that he is made uncomfortable by hearing words that describe his deeds. He states: "I had rather have my wounds to heal again/Than hear say how I got them" (73-74). He adds: "When blows have made me stay, I fled from words" (76), and exclaims again: "I had rather have one scratch my head i' th' sun/When the alarm were struck, than idly sit/To hear my nothings monster'd" (79-82). Although Marcius manages to withstand the discomfort of hearing the Senators report his honors, he balks at having to obtain the people's voices to secure the consulship he has earned. Brutus, the citizen's Tribune, recalls that Marcius has sworn that "never would he/Appear i' the marketplace, nor on him put/the napless vesture of humility,/Nor showing, as the manner is, his wounds/To th' people, beg their stinking breaths" (1I.II.248-52). Marcius believes that showing his wounds to the people would suggest that he had performed his valiant actions but "for the hire/of their breath only!" (II.III.152-53).

The subtext of the scene in the Forum, wherein Marcius does finally allow himself to be put on display for the citizens, is replete with repetition of the words "voice," and "tongue," as Coriolanus is physically engulfed by those who live by words. A citizen makes a pointed reference to what is happening on an emotional level when he notes: "If he show us his wounds and tells us his deeds, we are to put our tongues into those wounds 
and speak for them" (II.III.6-8). Coriolanus's mother, Volumnia, urges her son to use words as the people do, and speak not "by the matter which your heart prompts you,/But with such words that are but rooted in/Your tongue, though but bastards and syllables/of no allowance to your bosom's truth" (III.II.53-57). Marcius cannot accept such advise: "must I" he asks, "with my base tongue give to my noble heart/a lie that it must bear?" (99-101). Although the plebians award Marcius the consulship, Shakespeare makes it clear that their voices are just wind after all, for the Tribunes convince the people that they have made a mistake, and yielded their voices in "childish friendliness" (183) rather than from conviction. The emphasis on voices reaches its peak at the end of this scene when "five hundred voices" speak together against Marcius (218) and "twice five hundred and their friends" chime in from another group. With the withdrawal of the citizen's support Marcius, silent before, now sets loose his own voice against "the mutable, rank-scented many" (66) and against the foolish investiture of political power with the commoners, whose only "virtue" or "power" is that which the nobles have given them. He clearly resents a political structure which rests on voices, "where gentry, title, wisdom,/cannot conclude but by the yea and no/of general ignorance" (III.I.144-46). It is a further irony that lacking the flattering words that would make him consul, Marcius now has more than enough breath to voice ideas the Plebians will find traitorous.

When Marcius is brought before the people facing banishment, Shakespeare again emphasizes Marcius's disdain for men of words, even when their voices have the power to effect political consequences. He aggressively throws their word of banishment back in their faces:

You common cry of curs! Whose breath I hate

As reek o' th' rotten fens, whose loves I prize

As the dead carcasses of unburied men

That do corrupt my air, I banish you!

And here remain with your uncertainty!

Let every feeble rumour shake your hearts ... till at length

Your ignorance ... deliver you as most

Hated captives to some nation that won you without blows! (III.III.120-33)

Thus, Marcius has been rigidly consistent in his rejection of these men of words, and appropriately has left them to fall prey to men of deeds.

In these terms, the alliance of Marcius with Aufidius, his previous enemy in the war against the Volsces, is consistent with Marcius's character. Both Marcius and Aufidius are men of heart, having bravely encountered one another in battle "twelve several times" (IV.VI.128). Marcius sought out the most valiant man he had ever fought and sought to align himself with one who is capable of performing deeds of war against the Roman word-lovers.

In the last act of the play, Shakespeare adds a new concept in the subtext to the idea of words and breath. The breath that now assaults Rome is compared to that of a firebreathing dragon, as Marcius burns with curses everything that stands in his path. The Plebians again recant their earlier words in fear that Marcius will pay them in deeds for 
their words of banishment. True to his position as a politician, a man of words, Cominius intercepts Marcius and attempts to talk him out of waging war on Rome. Marcius, however, will not hear him; Cominius reports: "Coriolanus/He would not answer to; forbade all names;/He was a kind of nothing, titleless/Till he had forg'd himself a name 0 ' th' fire'/Of burning Rome" (V.I.11-15). Marcius, clearly, wishes to be avenged in deed, and will not allow words to affect his determination. Menenius, again attempts to find the words to move Marcius, but is told: "Mine ears against your suit are stronger than/Your gates against my force../Another word I will not hear thee speak" (V.II.93-99).

Had Marcius remained adamant in his refusal to hear words or speak to the Romans, his fate might have been different. But his mother, Volumnia, finally has the power to use the words that penetrate his armour. Shakespeare spends a great deal of time exploring this mother-son relationship, and makes it evident that Volumnia cares more about the image she has of her son, the honour he brings to her, than she does for his physical well-being. In the end, his mother refuses his command to "be silent and not speak" (V.III.94), and Coriolanus is forced to acknowledge the power of words when she reminds him of what history will say of him:

\section{... if thou conquer Rome, the benefit \\ Which thou shalt thereby reap is such a name \\ Whose repetition will be dogg'd with curses; \\ Whose chronicle thus writ: "The man was noble, \\ But with his last attempt he wip'd it out; \\ Destroyed his country; and his name remains \\ To the ensuing age abhorr'd." (V.III.142-48)}

Succumbing at last to the power of the words of the future through the image his mother has created of his cursed chronicle, he relents and asks Aufidius: "Would you have heard a mother less, or granted less, Aufidius?" The peace, he rationalizes, will be tangible, "a better witness ... than words." Yet, his end is tinged with irony. For saving Rome, Volumnia received the voices of the Romans in triumph, and Marcius is given a sentence of death with the very word which had caused him to leave Rome. Now it is the Volsces that pronounce him traitor, and ironically the words have more power than any deeds he had done in their behalf. Thus, to the end, Shakespeare's subtext heightens Coriolanus's conflict through persistent repetition of words associated with the politics of power.

As in Coriolanus, the subtext of The Tempest helps to focus the central issues in the face of extremely divergent interpretations. As Shakespeare's "farewell to his art," The Tempest is the most complicated in the canon, since it reflects all the major emphases of his work. This complexity has resulted in interpretations that range from the religious to the ridiculous, from the political to the psychological. Among these, numerous interpretations focus upon the central characters as representing different aspects of human nature. The four inhabitants of the island, for example, can be seen as the four humours of Renaissance psychology: in these terms Prospero is fire, the leader and creator; Miranda is feminine water, weeping and pliant; Ariel is, as his name suggests, air, imaginative and quick; while Caliban is, as Prospero calls him, "You earth." This basic scheme has been 
modernized in psychological interpretations which view each character as representing a part of the totality of the human psyche. Marilyn French notes: "The battle fought in this play is not among a set of characters, but within the psyche of one man who controls within himself, in varying degrees of acceptance, all of the qualities of all the poles" (320). Freudians add another level to this, interpreting Prospero as the driving intellect or ego, Caliban as the instinctual id, Miranda as the libido with her loving nature and desirability, and Ariel as the super-ego working to uplift and harmonize the others.

The temptation to schematize this play is evident even in critiques by poets. Although Robert Lowell is concerned with the play as poetry, he sees the characters as representing the various aspects of the writer's craft. Prospero, as the creative poet, commands the lyric fancy of Ariel, the realistic and grotesque comedy of Caliban, the pure poetry of Miranda, and the lyrical love poems of Ferdinand. The problem with this scheme, as with each of the others, is that it is reductive. Allegorical interpretations like this are ultimately unsatisfying, as they leave out as many possibilities as they explicate.

Thematic interpretations usually focus on one of three possibilities: education, politics or religion. The education theme, or "nature versus nurture" theme, which Frank Kermode has outlined remains a popular approach. Kermode, however, sees this conflict as focusing upon the relationships between Prospero and Caliban, in reference to Prospero's identification of Caliban as the "devil, on whose nature/Nurture can never stick" (IV.I.189). The play lends itself to a larger application of this idea, in which there is not only Caliban's nature, but Ariel's, Miranda's and all the other Neopolitan's natures which Prospero can attempt to nurture.

The political interpretation emphasizes Shakespeare's explorations of the rights and duties of governors, not only through the life on the island but also through the situation which caused Prospero's exile, and the political instability which the shipwrecked Neopolitans have brought with them. Marilyn French, for example, believes that The Tempest is "Shakespeare's attempt to delineate perfect (if not ultimate) justice within the terms of his world" (320), and, she adds, in this connection, the play explores the relationship between power and justice. There have been several overtly political productions in recent years, many based upon O. Mannoni's interpretation in Prospero and Caliban, which presents the island as a microcosm of power relationships depicting the evils of colonization. Jonathan Miller's production at the Mermaid Theatre in 1970 was one of the first to take this tack. Ralph Berry reports that the play was "set in a colonial island shortly before independence in which both Caliban and Ariel were played by black actors. On this showing, Caliban is the field hand and Ariel the house boy (who will eventually take over the administration)" (184). In this schematic interpretation, Caliban is the ungovernable native while Ariel is the educated aboriginal, trained by the ruling classes but left with all the problems when the colonizer, Prospero, leaves. The emphasis on power and justice in the play lends itself to this kind of political allegorization.

Moral and religious critics emphasize the theme of reconciliation in the play. In this view, each of the characters can be seen as one of the discordant elements in human society. Theodore Spencer and others seeking moral allegory see the play as a sustained meditation on the nature of man, asking what his possibilities and potentialities truly are. 
This question is implicity posed by the behaviour of all the people on the island but focuses primarily on Caliban.

The imagery studies of the play are less schematic. Virtually every essay mentions the abundance of sensual imagery and the variants of the storm/water imagery established by the title. Spurgeon feels that the images of the comedies in general are less specific than those of the other plays, and finds that The Tempest seems to be dominated by images that refer to abstract ideas. She also notes a predominance of images connected with sounds, particularly the "strange music" on the island and the sounds connected with the omnipresent sea and storm images (300). Subtextual references to water and tempest accompany the significant twists and turns in the psychological dramas being played out on the island, as no character is exempt from the "sea change/Into something rich and strange" that Ariel sings about (I.II.400-401). Each character uses these images somewhat differently, however. When, for example, the Neopolitans, Alonzo, Sebastian, Antonio, Gonzalo and the rest, refer to water, the mood is darker; they are frightened by the stormy sea and the subtext is filled with references to drowning. In opposition, Miranda's speeches are similarly full of references to water, but the violent storm and sea do not threaten her directly. For the most part, the water images refer to her sympathetic tears.

In addition to, and in combination with, the predominant images of sound and water, the subtext tends to focus upon two main modes of emotional emphasis, the exclamatory and the rebellious. The first is manifest in the repeated use of the simple exclamatory statement, "O!" This mode of wonder and amazement follows the adventures of each group of characters as they make new discoveries about themselves and Prospero's island. The mode begins with Miranda; her name itself suggests the amazement of her wondering innocence as the play opens. Prospero alone is exempt from amazement; each of the others finds something to wonder about, or, in the case of Ariel, is an agent of wonder to the others, able to "flame amazement" (I.II.195). The exclamatory mode moves from the frightened " $\mathrm{O}$, I have suffered," and " $\mathrm{O}$, heavens!" of the first scene, to Miranda's " $\mathrm{O}$, brave new world!" in Act V. Although each exclamation is couched in similar terms, each occurrence suggests significant information about the character experiencing amazement. Gonzalo's expression of surprise at the freshness of their garments after the shipwreck (II.I) suggests his optimistic nature and fundamental belief in the goodness in every experience. Stephano's and Trinculo's wonder at the "monster" Caliban (II.III) reflects not only their drunken hallucinations but their dark view of human nature and the "monsters" of which it consists. Ferdinand's notes of wonder at Miranda are very similar to Miranda's general exclamations at all the new people and experiences, and intimates that he shares her essentially innocent view of life and love. His stunned amazement at her beauty in its very mode of expression suggests that he is the perfect mate for her: "Admired Miranda!/Indeed the top of admiration! .. . Oh you,/So perfect and so peerless, are created/Of every creature's best!" (III.I.36-37, 46-48). Caliban's notes of wonder suggest a darker view of life. His is the primitive religious view which equates wonders with direct gifts and/or punishment from the gods. He readily falls to his knees in worship of Stephano and Trinculo for their gift of strange drink: "These be fine things, and if they be not sprites./That's a brave god and bears celestial liquor./I will kneel to him" (II.II.12122). Even at the end of the play when he realizes what fools his recent gods had proven 
to be, he falls back into his worshipful stance toward Prospero: "O Setebos, these be brave spirits indeed!/How fine my master is! I am afraid he will chastize me" (V.I.261-62). This persistent subtextual reference to amazement emphasizes the magical qualities of Prospero's kingdom as well as providing a note of optimism in the background to the pessimistic view permeating all the plots and schemes going on in the foreground.

The idea of amazement is frequently darkened by a variant on the word which also appears in the subtext. For example, although Ferdinand and Miranda have succumbed in amazement to the charms of love, Miranda's tears and Ferdinand's imprisonment also suggest some of the mazes into which love's wonders can lead. References to mazes, real and illusionary, appear throughout the subtext. Like Ferdinand, Gonzalo and the Neopolitans "tread a maze" (III.III.2) as they are led into confusion by Ariel. Alonzo also finds the island experiences to be "as strange a maze as e'er men trod" (V.I.242).

Amazement climaxes for Ferdinand and Miranda during Prospero's presentation of the magical masque. Prospero's hasty disruption of the masque when he realizes that he has an insurrection at hand indicates that wonder is all right for children and lovers, but Ferdinand and Miranda must heed the responsibilities of leadership as well. The breaking of the mode is significant, suggesting that wonder is only one of the possible responses to life, and one that has limited use amid the mazes of power politics.

Indeed, the note of wonder is counterpointed throughout by a mode of rebellion that derives from the political themes of the play. This is developed by reports of the various political machinations that went on in Naples and have continued on the island. The word that is tolled in the subtext in this context is "freedom" as each character on Prospero's island can be seen to be seeking freedom either from his situation of servitude, like Ariel and Caliban, or from past sins which have come back to haunt him, as in the case of Alonzo and Sebastian. References to freedom appear most frequently in scenes involving one of the recurring insurrections. There are many political upsets depicted in the play, and many more are planned. The first insurrection, Sebastian's overthrow of Prospero, took place before the play began. Prospero, in turn, exiled from Naples, took over the island from Sycorax, freeing Ariel who had been captured by the witch during her own usurpation of the island. Stephano and Trinculo plot with Caliban to overthrow Prospero, while Antonio and Sebastian plot against King Alonzo. As Jan Kott notes, on the island, "the history of the world will be played out in abbreviated form" in the struggle for power (170). In each case, a character is seeking either personal freedom or more power over others which he mistakenly believes will confer freedom.

The two modes, wonder and insurrection, eventually come together in the subtext. The mode of wonder joins the realistic political mode when Gonzalo summarizes the situation on the island in the last act: "All torment, trouble, wonder and amazement/Inhabits here" (V.I.104). Shakespeare indicates that both responses represent an aspect of human nature-life can be approached with wonder and awe or with anger and rebellion-but suggests, as well, that a mature vision tempers one with the other. Prospero's response to Miranda in the last scene makes this clear. She strikes her characteristic note when she sees all the strangers for the first time: " $\mathrm{O}$, wonder!/How many goodly creatures are there here!/How beauteous mankind is! O brave new world,/That has such people in 't!" (V.I.181-83). Prospero, however, pointedly responds: "Tis new to thee." Shakespeare thus 
suggests that an accurate assessment of life requires wondering amazement to be tempered by a recognition that the world is not only a "brave" place, but a place of power struggles and loss. The theological and moral issues raised by the play also coalesce here. Through the interweaving of the modes of wonder and rebellion, the subtext forces a recognition that both exclamations of amazement and cries for freedom inhabit the human heart.

Thus, we have seen that the subtext in each of these plays leads to the heart of Shakespeare's thematic interest. By sounding certain words throughout his subtext, Shakespeare leads his audience almost unconsciously to a fuller understanding of the complexities of human experience. By utilizing both the text (plot), and subtext (poetics), Shakespeare appeals to the total person, to both the intellectual and the emotional understanding of his audience. In each case we have explored, the subtext has led us directly to the center of the play's conflict. The subtext directs us to the nothing/nature polarity in Lear, to the seeing versus seeming disparity in Othello; to the golden chains of love and the chains of iron in A Comedy of Errors; to the contrast between nature's gifts and the gifts of fortune in As You Like It; to the dichotomy between the words that men live by in their political dealings with one another, and the deeds by which they prove their mettle in Coriolanus, and to the modes of wonder and rebellion in The Tempest. Through the interplay between text and subtext, Shakespeare develops his poetic intentions, enabling his audiences to "see feelingly" the paradoxes at the heart of human existence.

\section{Works Cited}

Berry, Ralph. Shakespeare and Social Class. Atlantic Highlands, New Jersey: Humanitics, 1988. Brooks, Harold. "Themes and Structures in The Comedy of Errors," in Early Shakespeare. London: Chatto and Windus, 1961.

Danby, John. Shakespeare's Doctrine of Nature: A Study of King Lear. London: 1961.

Clemen, Wolfgang. The Development of Shakespeare's Imagery. Cambridge: Harvard UP, 1951. Charlton, H.B. Shakespearean Tragedy. Cambridge: Cambridge UP, 1948.

Empson, William. "Honest In Othello." The Structure of Complex Words. London: Chatto and Windus, 1951.

French, Marilyn. Shakespeare's Division of Experience. New York: Random House, 1981. Gilman, Albert, ed. Signet As You Like It. New York: Signet, 1965.

Heilman, Robert. This Great Stage. Baton Rouge: U of Louisiana P, 1948.

Henze, Richard. "The Comedy of Errors: A Freely Binding Chain." Shakespeare Quarterly 22 (1971).

Kermode, Frank. Introduction to the Arden The Tempest. London: Oxford UP, 1964.

Knight, G. Wilson. The Imperial Theme. London: Methuen, 1931. . The Wheel of Fire. London: Methuen, 1947.

Knights, L. C. Some Shakespearean Themes. London: Chatto and Windus, 1959.

Kott, Jan. Shakespeare, Our Contemporary. Trans. Boreslaw Taborski. New York: Doubleday, 1964.

Mannoni, O. Prospero and Caliban: The Psychology of Colonization. Trans. Pamela Powesland. London: Macmillan, 1956.

Marowitz, Charles. "Nothingness in Peter Brook's Lear." Tulane Drama Review 8 (1963). 
Palmer, John. The Political Characters of Shakespeare. London: Macmillan, 1945.

Parrott, Marc. Shakespearean Comedy. New York, 1949.

Rossiter, A. P. Angel With Horns. Ed. Graham Storey. London, 1961.

Spencer, Theodore. Shakespeare and the Nature of Man. New York: Macmillan, 1942.

Spurgeon, Caroline. Shakespeare's Imagery. Cambridge: Cambridge UP, 1935.

Traversi, Derek. An Approach to Shakespeare. London: Methuen, 1938.

. "King Lear." Stratford Papers on Shakespeare. Ed. B. W. Jackson. Toronto: U of Toronto P, 1964. 